UDC: 631.53:633.15:632.165

DOI: $10.37128 / 2476626-2019-4-9$

\title{
STALK LODGING RESISTANCE OF CORN HYBRIDS DEPENDING ON THE PLANTING DATE
}

V.D. PALAMARCHUK, Candidate of Agricultural Sciences, Associate Professor O.M. KOLISNYK, Candidate of Agricultural Sciences, Associate Professor Vinnytsia National Agrarian University

Purpose. To study the effect of the planting date on the number of the lodged stalks, place of stem breaking and productivity of corn hybrids of various maturity groups. Methods. Field, laboratory, statistical. Results. In the studies, three planting dates were studied, in particular, early date with the soil temperature regime (STR) at the seeding depth of $+8^{\circ} \mathrm{C}$, mid date with $\mathrm{STR}-+10^{\circ} \mathrm{C}$ and late date with STR $+12^{\circ} \mathrm{C}$ for corn hybrids of different maturity groups (early group - Kharkivskyi 195MV, DKC 2870, DKC 2960, DKC 2949, DKC 2787, DKC 2971 (st), mid-early group - DKC 3476, DKC 3795, DKC 3472, DKC 3420, Pereiaslavskyi 230SV, DKC 3871 (st) and mid group - DK 391, DKC 3511, DK 440, DKC 4964, DKC 4626, $D K 315$ (st) and their effect on the productivity and number of the lodged stalks after a 15-day overripe in the field after full maturity of kernels. According to the research results, the number of lodged stalks in the group of early hybrids was $11.1 \%$, in the group of mid-early hybrids $-9.0 \%$, and in the group of mid hybrids $-6.2 \%$. So that hybrids with a longer growing season had higher lodging resistance than early forms due to better developed mechanical tissue of the lower stem. A significant change in the number of the lodged stalks was observed in the maturity groups depending on the genetic features of the hybrid (factor B). Hence, over the years of research, in the group of early hybrids, the smallest number of the lodged stalks, was observed in such hybrids as DKC 2960 - 4.9\% and DKC 2971 - 7.4\%, in the group of mid-early hybrids - DKC 3476 - 4.6\% and Pereiaslavskyi $230 S V-8.2 \%$, and in the group of mid hybrids - DKC 4964 - 3.6\%, DKC 4626 - 4.9\%, DK $391-5.1 \%$ and DK $440-$ $5.8 \%$. The research results also established the effect of the planting date on the productivity and number of the lodged stalks in the studied corn hybrids. Thus, on average over three years, under early planting, the number of the lodged stalks in the group of early hybrids was $17.1 \%$, in the group of mid-early hybrids $-14.3 \%$, and in the group of mid hybrids $-10.4 \%$, whereas when applying the second planting date the number of the lodged stalks was $10.5 \%, 7.3 \%$ and $6.1 \%$, while under late planting date $-5.6 \%, 5.4 \%$ and 2.2\%, respectively, for the early, mid-early and mid hybrid group of hybrids. Conclusions. Therefore, according to the research results it can be concluded that later planting date reduces both the total number of the lodged stalks (by 8.2-11.5\%) compared with the early sowing and the number of plants that have lodged below the place of cob formation (by 6.6-9.9\%). The smallest number of the lodged stalks (6.2\%) was observed in the hybrids of the mid group of maturity compared to the mid-early group (9.0\%) and early group (11.1\%) of hybrids. The same was observed with the number of the plants that have lodged below the cob$3.3 \%, 5.8 \%$ and $6.0 \%$. There has been established the dependence between the yield 
and number of the lodged stalks depending on the planting time, so that the yield ranged within 8,4-9,4 t/ha in the group of early hybrids under early planting , 7.2-8.7 t/ha under mid one, 6.4-7.7 t/ha under late one, and the number of fall lodged stalks $17.1 \%, 10.5 \%$ and $5.6 \%$ respectively under early planting, mid planting and late planting, in the mid-early group - 9.7-10.9 t/ha, under mid planting - 8.7-10.0 t/ha, late - 7.2-8.6 t/ha, and the number of the lodged stalks - 14.3\%, $7.3 \%$ and $5.4 \%$ and mid hybrids -11.5, 10.2 and 9.2 t/ha and 10.4, 6.1 and 2.2\%, respectively. According to the factor analysis, it has been established that the planting date makes a significant contribution (17\% of the total contribution) to the lodging resistance of plants of corn hybrids. The number of the lodged stalks varies considerably depending on the conditions of heat and moisture supply. An increase in the number of the lodged stalks was observed in 2012 (11.6\%), compared to 2011 (10.8\%) and 2013 (3.9\%) due to the moisture deficiency during the growing season of corn that year.

Keywords: grain, corn, hybrid, number of lodged stalks, maturity group, planting date, yield.

Tabl. 3. Fig. 1. Lit. 15.

Introduction. According to the Statistical Bulletin of Ukraine, the area of corn cultivation in Ukraine occupied 4.3-4.7 mln ha in 2015-2017, while in 2016 Ukraine hold an important place in the world by corn grain production having grown 28.07 $\mathrm{mln} t$ of corn with the average crop yield of $66.0 \mathrm{t} / \mathrm{ha}$ [1].

An increase in corn grain production is possible, firstly, due to the reduction of losses during harvesting operations. Annual loss of grain yield caused by plant lodging reaches $20 \%$, and sometimes it amounted to $20-40 \%$, especially in the cases of stalk breaking [2-5].

There are two types of lodging, namely stalk lodging and root lodging. Corn stalk lodging can be manifested at different stages of development, in particular in the panicle flowering stage, corn fill stage and after kernel maturation. When plant lodging occurs in the stages of growth and development, there can be observed a sharp decline in yield due to deterioration of photosynthetic processes in the lodged plants, root nutrition, outflow of nutrients into kernel, which results in the yield decrease, and at later stages, it leads to complications during combine harvesting [69].

Analysis of recent publications. On the one hand, stalk lodging resistance depends on the manifestation of traits that cause it, e.g. stem strength, flexibility (ability to withstand breakage) and structure, as well as the ability to root, i.e. the development of air roots and resistance to pests and diseases, and on the other hand, it depends on such farming techniques as plant nutrition, planting date, plant density, soil tillage, etc. $[4,5,9,10]$.

Therefore, the study of the effect of planting date on the corn stalk resistance to lodging is urgent and necessary. 
The purpose of the research was to study the effect of the planting date on the stalk lodging resistance, place of stem breaking and productivity of corn hybrids of different maturity groups.

Materials and methods. The research on the study of the effect of planting date on the complex of farming characteristics, including stalk lodging resistance and productivity of corn hybrids of different maturity groups, was carried out during 2011-2013. In the studies, hybrids of domestic breeding (Kharkivskyi 195MV and Pereiaslavskyi 230SV) and company "Monsanto" (DKC 2870, DKC 2960, DKC 2949, DKC 2787, DKC 2971, DKC 3476, DKC 3795, DKC 3472, DKC 3420, DKC 3871, DK 391, DKC 3511, DK 440, DKC 4964, DKC 4626, DK 315) were used as the most productive of three maturity groups, i.e. early, mid and mid-early groups.

Field studies were conducted in the SE EF "Kordelivske" of the IF NAAS of Ukraine, village Kordelivka, Kalynivka region, Vinnitsa oblast, which is located in the central part of the right-bank Forest-Steppe.

Soils were deep black mid-loamy on the loess. Humus content (by Tiurin) in the arable layer was $4.60 \%$. Reaction of soil solution - $\mathrm{pH}$ (salt) 5.7 (close to neutral); weighed average: hydrolytic acidity was $40 \mathrm{mg}$.-eq. per $1 \mathrm{~kg}$ of soil; the amount of absorbed bases was $158 \mathrm{mg}$.-eq. per $1 \mathrm{~kg}$ of soil (by Kappen-Gilkovits); the degree of saturation with the bases was $82.3 \%$.

According to agrometeorological observations, the main indicators of climatic conditions during the research years (2011-2013) were not similar to the average long-term data.

In 2011, the weather, which at first was cold and frosty, limited the use of the first (early) planting date in the first and second decades of April, so it was held on April 25. Due to the moisture deficiency, there was observed substantial uneven plant germination, especially as for the second planting period. Subsequently, the climatic conditions of 2011 differed little from the long-term and were favorable for corn growth and development.

The early spring of 2012 and unusually high temperatures of April provided unfavorable agro-climatic conditions for corn development. Thus, from May till the second decade of August, there was observed moisture deficiency, as evidenced by a significant deviation in precipitation during this period from those of average longterm.

In 2013, insufficient temperature indices and sufficient precipitation limited the use of early planting date, especially in the first decade of April. In the second and third decades of April there was observed a sharp increase in the temperature indices and moisture deficiency, which eventually affected the germination of corn hybrids in the second and third planting periods. In the future, the climatic conditions of 2013 differed little different from the long-term and were favorable for corn growth and development.

Planting was carried out by the upgraded seeder SUPN-8 at the seeding rate of 75 thousand seeds per hectare when there were proper soil temperature conditions at the seeding depth, in terms of the calendar it was the II-III decade of April - the first 
period of planting, May 1-2 was the second date, and the II-III decade of May was the third planting date. 3-4 time replication in experiments with hybrids was used. The sites were located by the method of randomized blocks. The sown area was $25 \mathrm{~m}^{2}$, the registration area was $10.5 \mathrm{~m}^{2}$.

Stalk lodging resistance of plants was assessed through a direct method. According to this method, corn lodging resistance is assessed by the number of the lodged stalks, expressed as a percentage of their total number on the experimental site after 15-20 days of overripe in the field. The plant is considered to be lodged if its main stem is inclined below $45^{\circ}$ to the surface of the soil [11-13]. Determination of the lodging resistance of corn hybrids involved application of the direct method of evaluation, in particular, counting of the lodged stalks after full maturity of kernels. In our research, we used a 15-day overripe [11, 13].

Evaluation of the maturity group was carried out in accordance with the duration of the growing season, classification of FAO, the number of leaves per plant and the number of veins on the perch leaf in accordance with the methodology of O.L. Zozulia (1992) *. Full maturity of kernels was determined by the black layer formation in the base of kernel as an element that stops the flow of nutrients to kernels and dying of the connecting tissues and moisture content in the kernel within 30-35\%.

Statistical processing of research results was carried out using a program software for statistical data analysis [14, 15].

Results and discussion. The effect of the planting date on the lodging resistance of corn hybrids grown for grain under a 15-day overripe under full maturity of kernels is shown is table 1.

According to the data given in Table 1, on average over three years of research, the number of the lodged stalks under 15-day overripe in the case of full maturity of kernels in the group of early hybrids (factor A) was $11.1 \%$, in the mid-early hybrids $9.0 \%$, and in the group of mid hybrids $-6.2 \%$. So that hybrids with a longer growing season had higher lodging resistance than early forms due to better developed mechanical tissue of the lower stem.

A significant change in the number of the lodged stalks was observed in the maturity groups depending on the genetic features of the hybrid (factor B). Hence, over the years of research, in the group of early hybrids, the smallest number of the lodged stalks, was observed in such hybrids as DKC 2960 - 4.9\% and DKC 2971 $7.4 \%$, in the group of mid-early hybrids - DKC $3476-4.6 \%$ and Pereiaslavskyi $230 \mathrm{CB}-8.2 \%$, and in the group of mid hybrids - DKC $4964-3.6 \%$, DKC $4626-$ $4.9 \%$, DK $391-5.1 \%$ and DK $440-5.8 \%$.

Under early planting date early corn hybrids had 7.3-54.2\% of the lodged stalks, in particular hybrid DKC 2787 - 37.8\%, 26.7\% and 15.3\%, Kharkivskyi 195 MB $12.9 \%, 54.2 \%$ and $17.5 \%$, DKC $2870-11.5 \%, 24.3 \%$ and $14.4 \%$, respectively, in 2011, 2012, and 2013. While the number of the lodged stalks in the standard DKC 2971 was $14.5 \%$, $8.0 \%$ and $6.5 \%$, respectively. 
Table 1

The effect of the planting date on the number of the lodged stalks of corn hybrids, \% (2011-2013 \pm Sx)

\begin{tabular}{|c|c|c|c|c|c|c|}
\hline \multirow{2}{*}{$\begin{array}{l}\text { Maturity } \\
\text { group } \\
\text { (factor A) }\end{array}$} & \multirow{2}{*}{ Hybrid (factor B) } & \multirow{2}{*}{$\begin{array}{l}\text { Planting date } \\
\text { (factor C) }\end{array}$} & \multicolumn{3}{|c|}{ Years of research } & \multirow{2}{*}{$\begin{array}{c}\text { Average of } 2011- \\
2013, \pm \text { Sx }\end{array}$} \\
\hline & & & 2011 & 2012 & 2013 & \\
\hline \multirow{18}{*}{$\begin{array}{l}\text { Early } \\
\text { group }\end{array}$} & \multirow{3}{*}{ Kharkivskyi 195MV } & Early $\left(\mathrm{STR}^{*} \mathrm{t}=+8^{\circ} \mathrm{C}\right)$ & 12.9 & 54.2 & 17.5 & $28.2 \pm 22.6$ \\
\hline & & $\operatorname{Mid}\left(\right.$ STR $\left.\mathrm{t}=+10^{\circ} \mathrm{C}\right)$ & 10.5 & 16.6 & 8.7 & $11.9 \pm 4.1$ \\
\hline & & Late (STR $\mathrm{t}=+12^{\circ} \mathrm{C}$ ) & 7.3 & 11.3 & 6.9 & $8.5 \pm 2.4$ \\
\hline & \multirow{3}{*}{ DKC 2870} & Early $\left(\mathrm{STR}^{*} \mathrm{t}=+8^{\circ} \mathrm{C}\right)$ & 11.5 & 24.3 & 7.3 & $14.4 \pm 8.9$ \\
\hline & & Mid $\left(\right.$ STR $\left.t=+10^{\circ} \mathrm{C}\right)$ & 9.3 & 18.0 & 4.9 & $10.7 \pm 6.7$ \\
\hline & & Late $\left(\mathrm{STR} t=+12^{\circ} \mathrm{C}\right)$ & 2.3 & 4.5 & 2.2 & $3.0 \pm 1.3$ \\
\hline & \multirow{3}{*}{ DKC 2960} & Early $\left(\mathrm{STR}^{*} \mathrm{t}=+8^{\circ} \mathrm{C}\right)$ & 14.5 & 7.8 & 0.0 & $7.4 \pm 7.3$ \\
\hline & & $\operatorname{Mid}\left(\right.$ STR $\left.t=+10^{\circ} \mathrm{C}\right)$ & 15.7 & 2.0 & 0.0 & $5.9 \pm 8.5$ \\
\hline & & Late $\left(\mathrm{STR} \mathrm{t}=+12^{\circ} \mathrm{C}\right)$ & 3.0 & 1.3 & 0.0 & $1.4 \pm 1.5$ \\
\hline & \multirow{3}{*}{ DKC 2949} & Early $\left(\mathrm{STR}^{*} \mathrm{t}=+8^{\circ} \mathrm{C}\right)$ & 15.7 & 20.3 & 12.3 & $16.1 \pm 4.0$ \\
\hline & & $\operatorname{Mid}\left(\mathrm{STR} \mathrm{t}=+10^{\circ} \mathrm{C}\right)$ & 12.3 & 9.0 & 4.5 & $8.6 \pm 3.9$ \\
\hline & & Late (STR $\mathrm{t}=+12^{\circ} \mathrm{C}$ ) & 4.3 & 3.3 & 4.6 & $4.1 \pm 0.7$ \\
\hline & \multirow{3}{*}{ DKC 2787} & Early $\left(\mathrm{STR}^{*} \mathrm{t}=+8^{\circ} \mathrm{C}\right)$ & 37.8 & 26.7 & 15.3 & $26.6 \pm 11.3$ \\
\hline & & Mid $\left(\right.$ STR $\left.t=+10^{\circ} \mathrm{C}\right)$ & 24.0 & 25.6 & 5.9 & $18.5 \pm 10.9$ \\
\hline & & Late $\left(\right.$ STR $\left.\mathrm{t}=+12^{\circ} \mathrm{C}\right)$ & 10.7 & 17.0 & 7.8 & $11.8 \pm 4.7$ \\
\hline & \multirow{3}{*}{ DKC 2971 (st) } & Early $\left(\operatorname{STR}^{*} \mathrm{t}=+8^{\circ} \mathrm{C}\right)$ & 14.5 & 8.0 & 6.5 & $9.7 \pm 4.3$ \\
\hline & & $\operatorname{Mid}\left(\mathrm{STR} t=+10^{\circ} \mathrm{C}\right)$ & 14.7 & 3.5 & 4.2 & $7.5 \pm 6.3$ \\
\hline & & Late $\left(\mathrm{STR} t=+12^{\circ} \mathrm{C}\right)$ & 8.7 & 2.5 & 3.8 & $5.0 \pm 3.3$ \\
\hline \multirow{18}{*}{ 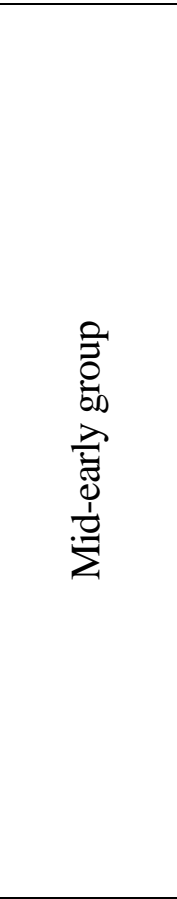 } & \multirow{3}{*}{ DKC 3476} & Early $\left(\mathrm{STR}^{*} \mathrm{t}=+8^{\circ} \mathrm{C}\right)$ & 4.9 & 16.0 & 0.0 & $7.0 \pm 8.2$ \\
\hline & & $\operatorname{Mid}\left(\mathrm{STR} \mathrm{t}=+10^{\circ} \mathrm{C}\right)$ & 4.3 & 7.0 & 0.0 & $3.8 \pm 3.5$ \\
\hline & & Late $\left(\right.$ STR $\left.\mathrm{t}=+12^{\circ} \mathrm{C}\right)$ & 4.0 & 5.3 & 0.0 & $3.1 \pm 2.8$ \\
\hline & \multirow{3}{*}{ DKC 3795} & Early $\left(\mathrm{STR}^{*} \mathrm{t}=+8^{\circ} \mathrm{C}\right)$ & 14.6 & 24.3 & 10.4 & $16.4 \pm 7.1$ \\
\hline & & $\operatorname{Mid}\left(\right.$ STR $\left.t=+10^{\circ} \mathrm{C}\right)$ & 12.7 & 9.7 & 0.0 & $7.5 \pm 6.6$ \\
\hline & & Late $\left(\right.$ STR $\mathrm{t}=+12^{\circ} \mathrm{C}$ ) & 8.0 & 6.0 & 0.0 & $4.7 \pm 4.2$ \\
\hline & \multirow{3}{*}{ DKC 3472} & Early $\left(\mathrm{STR}^{*} \mathrm{t}=+8^{\circ} \mathrm{C}\right)$ & 17.9 & 27.3 & 8.7 & $18.0 \pm 9.3$ \\
\hline & & $\operatorname{Mid}\left(\mathrm{STR} t=+10^{\circ} \mathrm{C}\right)$ & 11.3 & 11.3 & 0.0 & $7.5 \pm 6.5$ \\
\hline & & Late $\left(\mathrm{STR} \mathrm{t}=+12^{\circ} \mathrm{C}\right)$ & 3.7 & 8.2 & 2.1 & $4.7 \pm 3.2$ \\
\hline & \multirow{3}{*}{ DKC 3420} & Early $\left(\mathrm{STR}^{*} \mathrm{t}=+8^{\circ} \mathrm{C}\right)$ & 10.4 & 16.3 & 11.5 & $12.7 \pm 3.1$ \\
\hline & & $\operatorname{Mid}\left(\mathrm{STR} t=+10^{\circ} \mathrm{C}\right)$ & 8.7 & 12.7 & 2.7 & $8.0 \pm 5.0$ \\
\hline & & Late $\left(\mathrm{STR} t=+12^{\circ} \mathrm{C}\right)$ & 4.3 & 15.0 & 1.5 & $6.9 \pm 7.1$ \\
\hline & \multirow{3}{*}{ Pereislavskyi 230SV } & Early $\left(\mathrm{STR}^{*} \mathrm{t}=+8^{\circ} \mathrm{C}\right)$ & 14.3 & 29.3 & 0.0 & $14.5 \pm 14.7$ \\
\hline & & Mid $\left(\right.$ STR $\left.\mathrm{t}=+10^{\circ} \mathrm{C}\right)$ & 10.3 & 8.0 & 0.0 & $6.1 \pm 5.4$ \\
\hline & & Late (STR $\left.\mathrm{t}=+12^{\circ} \mathrm{C}\right)$ & 4.0 & 8.2 & 0.0 & $4.1 \pm 4.1$ \\
\hline & \multirow{3}{*}{ DKC 3871 (st) } & Early $\left(\mathrm{STR}^{*} \mathrm{t}=+8^{\circ} \mathrm{C}\right)$ & 15.1 & 25.3 & 10.5 & $17.0 \pm 7.6$ \\
\hline & & $\operatorname{Mid}\left(\mathrm{STR} t=+10^{\circ} \mathrm{C}\right)$ & 11.3 & 14.0 & 6.5 & $10.6 \pm 3.8$ \\
\hline & & Late $\left(\mathrm{STR} t=+12^{\circ} \mathrm{C}\right)$ & 12.5 & 13.2 & 2.0 & $9.2 \pm 6.3$ \\
\hline \multirow{6}{*}{ 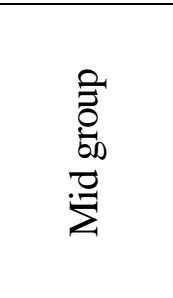 } & \multirow{3}{*}{ DK 391} & Early $\left(\mathrm{STR}^{*} \mathrm{t}=+8^{\circ} \mathrm{C}\right)$ & 15.4 & 4.7 & 3.5 & $7.9 \pm 6.6$ \\
\hline & & $\operatorname{Mid}\left(\right.$ STR $\left.t=+10^{\circ} \mathrm{C}\right)$ & 12.0 & 2.1 & 0.0 & $4.7 \pm 6.4$ \\
\hline & & Late $\left(\mathrm{STR} t=+12^{\circ} \mathrm{C}\right)$ & 4.0 & 3.0 & 1.5 & $2.8 \pm 1.3$ \\
\hline & \multirow{3}{*}{ DKC 3511} & Early $\left(\operatorname{STR}^{*} \mathrm{t}=+8^{\circ} \mathrm{C}\right)$ & 29.2 & 18.0 & 7.7 & $18.3 \pm 10.8$ \\
\hline & & $\operatorname{Mid}\left(\right.$ STR $\left.t=+10^{\circ} \mathrm{C}\right)$ & 26.7 & 11.8 & 0.0 & $12.8 \pm 13.4$ \\
\hline & & Late (STR $\mathrm{t}=+12^{\circ} \mathrm{C}$ ) & 5.3 & 1.9 & 0.0 & $2.4 \pm 2.7$ \\
\hline
\end{tabular}




\begin{tabular}{|c|c|c|c|c|c|c|}
\hline \multirow{18}{*}{ 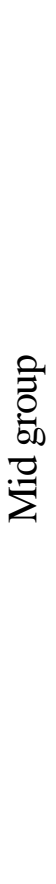 } & \multirow{3}{*}{ DK 391} & Early $\left(\mathrm{STR}^{*} \mathrm{t}=+8^{\circ} \mathrm{C}\right)$ & 15.4 & 4.7 & 3.5 & $7.9 \pm 6.6$ \\
\hline & & $\operatorname{Mid}\left(\mathrm{STR} t=+10^{\circ} \mathrm{C}\right)$ & 12.0 & 2.1 & 0.0 & $4.7 \pm 6.4$ \\
\hline & & Late $\left(\mathrm{STR} \mathrm{t}=+12^{\circ} \mathrm{C}\right)$ & 4.0 & 3.0 & 1.5 & $2.8 \pm 1.3$ \\
\hline & \multirow{3}{*}{ DKC 3511} & Early $\left(\mathrm{STR}^{*} \mathrm{t}=+8^{\circ} \mathrm{C}\right)$ & 29.2 & 18.0 & 7.7 & $18.3 \pm 10.8$ \\
\hline & & $\operatorname{Mid}\left(\mathrm{STR} t=+10^{\circ} \mathrm{C}\right)$ & 26.7 & 11.8 & 0.0 & $12.8 \pm 13.4$ \\
\hline & & Late (STR t=+12 ${ }^{\circ} \mathrm{C}$ ) & 5.3 & 1.9 & 0.0 & $2.4 \pm 2.7$ \\
\hline & \multirow{3}{*}{ DK 440} & $\operatorname{Early}\left(\mathrm{STR}^{*} \mathrm{t}=+8^{\circ} \mathrm{C}\right)$ & 13.7 & 8.0 & 6.8 & $9.5 \pm 3.7$ \\
\hline & & $\operatorname{Mid}\left(\operatorname{STR} \mathrm{t}=+10^{\circ} \mathrm{C}\right)$ & 10.0 & 5.3 & 0.0 & $5.1 \pm 5.0$ \\
\hline & & Late $\left(\right.$ STR $\left.\mathrm{t}=+12^{\circ} \mathrm{C}\right)$ & 5.3 & 2.8 & 0.0 & $2.7 \pm 2.7$ \\
\hline & \multirow{3}{*}{ DKC 4964} & Early $\left(\mathrm{STR}^{*} \mathrm{t}=+8^{\circ} \mathrm{C}\right)$ & 6.5 & 5.7 & 5.1 & $5.8 \pm 0.7$ \\
\hline & & $\operatorname{Mid}\left(\mathrm{STR} t=+10^{\circ} \mathrm{C}\right)$ & 5.0 & 3.8 & 3.1 & $4.0 \pm 1.0$ \\
\hline & & Late $\left(\mathrm{STR} \mathrm{t}=+12^{\circ} \mathrm{C}\right)$ & 1.7 & 1.4 & 0.0 & $1.0 \pm 0.9$ \\
\hline & \multirow{3}{*}{ DKC 4626} & Early $\left(\mathrm{STR}^{*} \mathrm{t}=+8^{\circ} \mathrm{C}\right)$ & 10.2 & 9.3 & 6.4 & $8.6 \pm 2.0$ \\
\hline & & $\operatorname{Mid}\left(\operatorname{STR} \mathrm{t}=+10^{\circ} \mathrm{C}\right)$ & 8.3 & 6.6 & 0.0 & $5.0 \pm 4.4$ \\
\hline & & Late $\left(\right.$ STR $\left.\mathrm{t}=+12^{\circ} \mathrm{C}\right)$ & 1.3 & 2.0 & 0.0 & $1.1 \pm 1.0$ \\
\hline & \multirow{3}{*}{ DK 315 (st) } & Early $\left(\mathrm{STR}^{*} \mathrm{t}=+8^{\circ} \mathrm{C}\right)$ & 15.6 & 15.0 & 6.5 & $12.4 \pm 5.1$ \\
\hline & & $\operatorname{Mid}\left(\mathrm{STR} t=+10^{\circ} \mathrm{C}\right)$ & 7.7 & 6.1 & 1.0 & $4.9 \pm 3.5$ \\
\hline & & Late $\left(\right.$ STR $\left.\mathrm{t}=+12^{\circ} \mathrm{C}\right)$ & 3.3 & 3.5 & 2.0 & $2.9 \pm 0.8$ \\
\hline
\end{tabular}

Note: STR - soil temperature regime at the seeding depth

$\mathrm{LSD}_{05}$, \% for 2011: Factor A - 0.3; Factor B - 0.9; Factor C - 0.5.

$\mathrm{LSD}_{05}$, \% for 2012: Factor A - 0.6; Factor B - 1.3; Factor C - 0.6.

$\mathrm{LSD}_{05}$, \% for 2013: Factor A - 0.5; Factor B - 0.5; Factor C - 0.4.

Source: formed on the basis of own research results

The research results also established the effect of the planting date (factor $\mathrm{C}$ ) on the number of the lodged stalks in the studied corn hybrids. Thus, on average over three years, under early planting, the number of the lodged stalks in the group of early hybrids was $17.1 \%$, in the mid-early hybrids - $14.3 \%$, and in the group of mid hybrids $-10.4 \%$, whereas when applying the second planting date the number of the lodged stalks was $10.5 \%, 7.3 \%$ and $6.1 \%$, while under late planting date $-5.6 \%$, $5.4 \%$ and $2.2 \%$, respectively, for the early, mid-early and mid hybrid group of hybrids.

When planting early hybrids in the mid-term (when the soil temperature is + 8$10^{\circ} \mathrm{C}$ ), there can be observed a decrease in the number of the lodged stalks, both on average over the years of research and by the years of research. The largest number of the lodged stalks was observed in the following hybrids: DKC $2787-24.0 \%$, 25.6\% and 5.9\%, Kharkivskyi $195 \mathrm{MB}-10.5 \%, 16.6 \%$ and 8.7\%, DKC $2870-$ 9.3\%, 18.0\% and 4.9\%, respectively, in 2011, 2012, and 2013 .

Late planting of corn provided the smallest number of the lodged stalks in the studied hybrids, compared to the early and mid planting. This is explained by the fact that under early planting date the height of plants varies and the harmfulness of Pyrausta nubilalis $\mathrm{Hb}$. as the main factor of lodging is chanded. The largest number of the lodged stalks under late planting was observed in such hybrids as DKC 2787 10.7\%, 17.0\% and 7.8\%, Kharkivskyi $195 \mathrm{MB}-7.3 \%, 11.3 \%$ and 6.9\%, DKC 2971 $-8.7 \%, 2.5 \%$ and 3.8\%, respectively in 2011, 2012, and 2013. 
In the group of mid-early hybrids, under early planting date, the largest number of the lodged stalks was observed in DKC $3472-17.9 \%, 27.3$ and 8.7\%, DKC 3871 - 15.1\%, 25.3\% and 10.5\%, DKC 3795 - 14.6\%, 24.3\% and 10.4\%, respectively, in 2011, 2012, and 2013. In hybrids Pereiaslavskyi 230MB - 14.0\% and 29.3\%, respectively, in 2011 and 2012, while in 2013 lodged stalks were not observed in this hybrid.

Similar to the group of early hybrids, a decrease in the number of the lodged stalks was observed under late planting date and soil temperature at the seeding depth $+10-12{ }^{\circ} \mathrm{C}$. In the course of research, it was noted that the number of the lodged stalks depended not only on the group of the hybrid maturity, biological characteristics and planting term, but it also significantly varied depending on the conditions of heat and moisture supply. The increase in the number of the lodged stalks in most of the studied corn hybrids was observed in 2012 (on average 11.6\%), compared to 2011 (10.8\%) and 2013 (3.9\%), due to moisture deficiency during the growing season of corn and high positive temperatures during that year.

A factor analysis was carried out to estimate the share of the effect of each factor on the lodging resistance of corn hybrids of different maturity groups (Fig. 1).

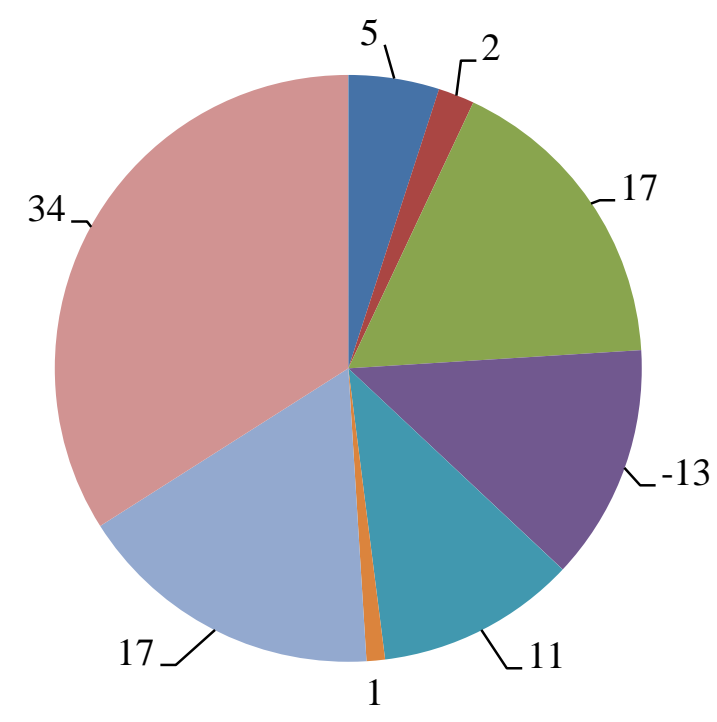

A

$\square \mathrm{B}$

$\square \mathrm{C}$

$\square \mathrm{AC}$

$\mathrm{AB}$

$\square \mathrm{BC}$

$\square \mathrm{ABC}$

remainder

Fig. 1. Factor analysis of the planting date on the lodging resistance of corn hybrids (average of 2011-2013)

Share of factor effect

Interaction $\mathrm{ABC} 17 \%$

Factor C

Residual 34\%

Source: formed on the basis of own research results

According to the data of the factor analysis, it has been established that the planting date (factor C) makes a significant contribution (17\% of total contribution) to the stalk lodging resistance of corn hybrids. In addition, it is necessary to note the decrease in the share of the effect of genetic hybrid features (factor B) to $2 \%$ in the case the planting date is changed, which clearly demonstrates the decrease or increase 
in the number of the lodged stalks due to the change of the planting date even in hybrids, which showed high or low lodging resistance. The maturity group had a 5\% effect on the corn stalk lodging resistance.

When assessing the risk of lodging, it is important to consider the place of stem breaking, in particular lodging above the cob minimizes cob contact with the soil and pathogenic microflora, and these lodged cobs can be threshed during mechanized harvesting, but if the lodging occurs below the place of cob formation, then these cobs are damaged by diseases and pests, have high moisture content in the kernels and they cannot be mechanically harvested.

Assessment of the number of lodged stalks of corn hybrids below the place of cob formation depending on the planting date is given in Table 2 .

Table 2

The number of plants of corn hybrids lodged below the cob depending on the planting date, $\%$ (average of 2011-2013 \pm Sx)

\begin{tabular}{|c|c|c|c|c|c|c|c|c|c|c|}
\hline \multirow{4}{*}{ 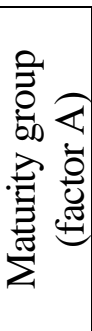 } & \multirow{4}{*}{$\begin{array}{c}\text { Name of the hybrid } \\
\text { (factor B) }\end{array}$} & \multicolumn{9}{|c|}{ Planting date (factor C) } \\
\hline & & \multicolumn{3}{|c|}{ Early $\left(\mathrm{STR}^{*} \mathrm{t}=+8^{\circ} \mathrm{C}\right)$} & \multicolumn{3}{|c|}{$\operatorname{Mid}\left(\right.$ STR $\left.\mathrm{t}=+10^{\circ} \mathrm{C}\right)$} & \multicolumn{3}{|c|}{ Late $\left(\right.$ STR $\mathrm{t}=+12^{\circ} \mathrm{C}$ ) } \\
\hline & & \multicolumn{2}{|c|}{ Lodged plants, \% } & \multirow{2}{*}{ 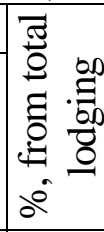 } & \multicolumn{2}{|c|}{ Lodged plants, \% } & \multirow{2}{*}{ 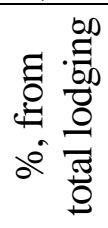 } & \multicolumn{2}{|c|}{ Lodged plants, \% } & \multirow{2}{*}{ 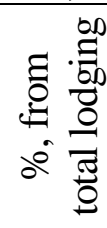 } \\
\hline & & total & $\begin{array}{l}\text { below } \\
\text { cob }\end{array}$ & & total & $\begin{array}{c}\text { below } \\
\text { cob }\end{array}$ & & total & $\left|\begin{array}{c}\text { Below } \\
\text { cob }\end{array}\right|$ & \\
\hline \multirow{6}{*}{ 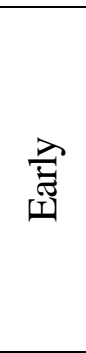 } & $\begin{array}{ll}\text { Kharkivskyi } 195 \\
\text { MV }\end{array}$ & $28.2 \pm 22.6$ & $18.9 \pm 17.5$ & 66.9 & $11.9 \pm 4.1$ & $6.0 \pm 5.6$ & 50.6 & $8.5 \pm 2.4$ & $4.2 \pm 2.9$ & 49.4 \\
\hline & DKC 2870 & $14.4 \pm 8.9$ & $8.9 \pm 5.8$ & 61.7 & $10.7 \pm 6.7$ & $6.7 \pm 6.3$ & 62.4 & $3.0 \pm 1.3$ & $1.0 \pm 1.7$ & 33.3 \\
\hline & DKC 2960 & $7.4 \pm 7.3$ & $6.0 \pm 6.9$ & 80.7 & $5.9 \pm 8.5$ & $3.3 \pm 4.9$ & 56.5 & $1.4 \pm 1.5$ & $0.0 \pm 0.0$ & 0.0 \\
\hline & DKC 2949 & $16.1 \pm 4.0$ & $10.7 \pm 3.7$ & 66.3 & $8.6 \pm 3.9$ & $4.3 \pm 2.7$ & 50.4 & $4.1 \pm 0.7$ & $0.3 \pm 0.6$ & 8.2 \\
\hline & DKC 2787 & $26.6 \pm 11.3$ & $15.4 \pm 13.1$ & 57.9 & $18.5 \pm 10.9$ & $9.5 \pm 6.2$ & 51.4 & $11.8 \pm 4.7$ & $1.3 \pm 1.2$ & 11.3 \\
\hline & DKC 2971 (st) & $9.7 \pm 4.3$ & $7.1 \pm 5.1$ & 73.1 & $7.5 \pm 6.3$ & $3.7 \pm 3.2$ & 49.1 & $5.0 \pm 3.3$ & $0.6 \pm 1.0$ & 11.3 \\
\hline \multirow{6}{*}{ 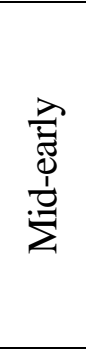 } & DKC 3476 & $7.0 \pm 8.2$ & $5.8 \pm 6.8$ & 83.7 & $3.8 \pm 3.5$ & $1.2 \pm 1.6$ & 31.9 & $3.1 \pm 2.8$ & $0.7 \pm 1.2$ & 21.5 \\
\hline & DKC 3795 & $16.4 \pm 7.1$ & $12.0 \pm 7.2$ & 73.2 & $7.5 \pm 6.6$ & $3.7 \pm 3.3$ & 50.0 & $4.7 \pm 4.2$ & $1.9 \pm 1.7$ & 41.4 \\
\hline & DKC 3472 & $18.0 \pm 9.3$ & $13.1 \pm 8.9$ & 72.9 & $7.5 \pm 6.5$ & $5.6 \pm 4.9$ & 74.3 & $4.7 \pm 3.2$ & $1.5 \pm 2.3$ & 32.1 \\
\hline & DKC 3420 & $12.7 \pm 3.1$ & $9.7 \pm 2.7$ & 75.9 & $8.0 \pm 5.0$ & $3.5 \pm 3.5$ & 43.2 & $6.9 \pm 7.1$ & $3.6 \pm 6.0$ & 52.4 \\
\hline & $\begin{array}{l}\text { Pereiaslavskyi } 230 \\
\text { SV }\end{array}$ & 14.5 & .1 & 75.0 & 5.4 & -3.3 & 60.7 & 4.1 & $1.7 \pm 2.4$ & 42.6 \\
\hline & DKC 3871 (st) & $17.0 \pm 7.6$ & $11.9 \pm 5.6$ & 69.9 & $10.6 \pm 3.8$ & $7.4 \pm 4.7$ & 69.5 & $9.2 \pm 6.3$ & $5.6 \pm 5.2$ & 60.3 \\
\hline \multirow{6}{*}{$\sum_{i}$} & DK 391 & $7.9 \pm 6.6$ & $5.1 \pm 6.3$ & 65.3 & $4.7 \pm 6.4$ & $2.4 \pm 4.2$ & 51.1 & $2.8 \pm 1.3$ & $0.0 \pm 0.0$ & 0.0 \\
\hline & DKC 3511 & $18.3 \pm 10.8$ & $12.6 \pm 7.4$ & 68.9 & $12.8 \pm 13.4$ & $7.7 \pm 8.2$ & 60.0 & $2.4 \pm 2.7$ & $0.5 \pm 0.9$ & 22.2 \\
\hline & DK 440 & $9.5 \pm 3.7$ & $6.2 \pm 3.9$ & 65.6 & $5.1 \pm 5.0$ & $2.5 \pm 2.6$ & 49.7 & $2.7 \pm 2.7$ & $0.2 \pm 0.3$ & 7.4 \\
\hline & DKC 4964 & $5.8 \pm 0.7$ & $3.3 \pm 2.2$ & 56.6 & $4.0 \pm 1.0$ & $0.9 \pm 0.2$ & 22.7 & $1.0 \pm 0.9$ & $0.1 \pm 0.2$ & 12.9 \\
\hline & \begin{tabular}{|l} 
DKC 4626 \\
\end{tabular} & $8.6 \pm 2.0$ & $6.5 \pm 2.6$ & 74.9 & $5.0 \pm 4.4$ & $2.1 \pm 1.8$ & 42.3 & $1.1 \pm 1.0$ & $0.2 \pm 0.3$ & 18.2 \\
\hline & DK 315 (st) & $12.4 \pm 5.1$ & $7.4 \pm 4.3$ & 59.8 & $4.9 \pm 3.5$ & $1.7 \pm 1.5$ & 35.1 & $2.9 \pm 0.8$ & $0.5 \pm 0.5$ & 17.0 \\
\hline \multicolumn{2}{|c|}{$\begin{array}{l}\mathrm{LSD}_{05}, \% \text { for the total } \\
\text { lodging }\end{array}$} & \multicolumn{9}{|c|}{ Factor A - 4.7; B - 5.6; C - 1.8. } \\
\hline
\end{tabular}

Note: STR - soil temperature regime at the seeding depth

Source: formed on the basis of own research results 
On average over three years of research, the number of plants lodged below the cob in the early group amounted to $6.0 \%$, mid-early group $-5.8 \%$, and mid group $3.3 \%$. When describing the data in Table 2, it should be noted that over the years of research under early planting in the group of early hybrids the number of plants lodged below the cob ranged within $6.0-18.9 \%$, which was $57.9-80.7 \%$ of total lodging, under mid planting - 3.3-9.5\% of plants lodged below the cob, or 49.1$62.4 \%$ of the total lodging, and under late planting $-0.3-4.2 \%$ and $8.2-49.4 \%$ of the total lodging. In the group of mid-early hybrids, the number of plants lodged below the cob under early planting date was $5.8-13.1 \%$, which was $69.9-83.7 \%$ of the total lodging, under mid planting date $-1.2-7.4 \%$ of plants lodged below the cob, or 31.9$74.3 \%$ of the total lodging, and under late lodging $-0.7-5.6 \%$, or $20.4-60.3 \%$ of the total lodging.

Mid-early hybrids had the smallest number of the lodged stalks and plants that lodged below the cob, compared with the early and mid-early hybrids. That was primarily due to the features of the anatomical and morphological structure of the stem, development of the sclerenchymal ring of the mechanical tissues of the lower intestine, and with fewer plants damaged by Pyrausta nubilalis $\mathrm{Hb}$.

The number of plants lodged below the cob under early planting was 2.6-12.6\% in mid hybrids, which was $52.3-74.9 \%$ of the total lodging, under mid planting date $0.9-7.7 \%$ of the plants lodged below the cob, or $22.7-60.0 \%$ of the total lodging, and under late planting $-0.1-0.5 \%$, or $7.4-22.2 \%$ of the total lodging.

In 2012, due to the stress related to moisture supply, there was observed such a negative phenomenon as stem lodging of some corn hybrids, which is called "goose neck" in the literature. Such kind of lodging was observed, to a greater extent, in the following hybrids: DKC 4626 - 22.0\%, DKC 2787 - 10\%, DKC 3781 - 10.5\%.

The data given in Table 3 demonstrate the decrease in crop yield caused by the change in the planting date and stalk lodging in corn hybrids of different maturity groups.

Analyzing data on the yield, it should be noted that the yield of one and the same hybrid may change over the years of research. 2012 appeared to be the least favorable for the formation of productivity of maize hybrids $(8.16 \mathrm{t} / \mathrm{ha})$, which was characterized by the increased positive temperatures and lack of sufficient precipitation for corn and a significant percentage of the lodged stalks, whereas in 2011 grain yield in the studied hybrids was $9.81 \mathrm{t} / \mathrm{ha}$, and in 2013 it was $9.38 \mathrm{t} / \mathrm{ha}$.

It is also worth noting the increase in the yield of corn hybrids with a long growing period (1.0-2.3 t/ha) compared to early forms (LSD 05 maturity group factor $\mathrm{A}=$ $0.22 \mathrm{t} / \mathrm{ha}$ ). Thus, on average over three years the yield of early corn hybrids amounted to $8.0 \mathrm{t} / \mathrm{ha}$, mid-early $-9.0 \mathrm{t} / \mathrm{ha}$ and mid $-10.3 \mathrm{t} / \mathrm{ha}$. It should be noted that in the mid group, on average over three years, along with the yield increase, the number of the lodged stalks decreases by $4.9 \%$.

On average over three years of research, the highest grain yield, was formed by the hybrids of the early group - DKC $2971-8.5 \mathrm{t} / \mathrm{ha}$, DKC $2960-8.4 \mathrm{t} / \mathrm{ha}$, and DKC 2787 - 8.3 t / ha, mid-early group DKC 3472 - 9.9 t / ha, DKC 3871, DKC 3476 and 
Table 3

The effect of the planting date on the yield of corn hybrids of different maturity groups, g (average of 2011-2013 \pm Sx)

\begin{tabular}{|c|c|c|c|c|c|c|}
\hline \multirow{2}{*}{ 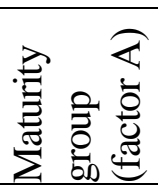 } & \multirow[b]{2}{*}{ Hybrid (factor B) } & \multirow[b]{2}{*}{ Planting date (factor C) } & \multicolumn{3}{|c|}{ Years of research } & \multirow{2}{*}{$\begin{array}{c}\text { average of } \\
\text { 2011-2013 } \\
\quad \pm \text { Sx }\end{array}$} \\
\hline & & & 2011 & 2012 & 2013 & \\
\hline 1 & 2 & 3 & 4 & 5 & 6 & 7 \\
\hline \multirow{18}{*}{ 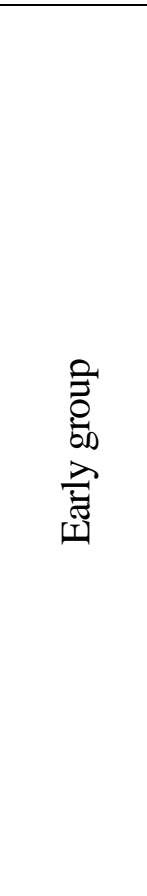 } & \multirow{3}{*}{ Kharkivskyi195MV } & Early $\left(\mathrm{STR}^{*} \mathrm{t}=+8^{\circ} \mathrm{C}\right)$ & 9.6 & 8.1 & 8.5 & $8.7 \pm 0.8$ \\
\hline & & $\operatorname{Mid}\left(\mathrm{STR}=+10^{\circ} \mathrm{C}\right)$ & 9.0 & 7.5 & 8.2 & $8.2 \pm 0.8$ \\
\hline & & Late $\left(\mathrm{STR} \mathrm{t}=+12^{\circ} \mathrm{C}\right)$ & 7.5 & 6.1 & 6.8 & $6.8 \pm 0.7$ \\
\hline & \multirow{3}{*}{ DKC 2870} & Early $\left(\mathrm{STR}^{*} \mathrm{t}=+8^{\circ} \mathrm{C}\right)$ & 9.6 & 8.3 & 8.9 & $8.9 \pm 0.7$ \\
\hline & & $\operatorname{Mid}\left(\mathrm{STR}=+10^{\circ} \mathrm{C}\right)$ & 8.2 & 7.1 & 8.8 & $8.0 \pm 0.9$ \\
\hline & & Late $\left(\mathrm{STR} \mathrm{t}=+12^{\circ} \mathrm{C}\right)$ & 7.4 & 6.1 & 6.4 & $6.6 \pm 0.7$ \\
\hline & \multirow{3}{*}{ DKC 2960} & Early $\left(\mathrm{STR}^{*} \mathrm{t}=+8^{\circ} \mathrm{C}\right)$ & 11.3 & 8.0 & 9.0 & $9.4 \pm 1.7$ \\
\hline & & $\operatorname{Mid}\left(\mathrm{STR}=+10^{\circ} \mathrm{C}\right)$ & 9.2 & 7.2 & 8.9 & $8.4 \pm 1.1$ \\
\hline & & Late $\left(\mathrm{STR} t=+12^{\circ} \mathrm{C}\right)$ & 8.0 & 6.3 & 7.8 & $7.4 \pm 0.9$ \\
\hline & \multirow{3}{*}{ DKC 2949} & Early $\left(\mathrm{STR}^{*} \mathrm{t}=+8^{\circ} \mathrm{C}\right)$ & 9.3 & 7.2 & 8.5 & $8.3 \pm 1.1$ \\
\hline & & $\operatorname{Mid}\left(\mathrm{STR}=+10^{\circ} \mathrm{C}\right)$ & 7.7 & 6.5 & 7.3 & $7.2 \pm 0.6$ \\
\hline & & Late $\left(\mathrm{STR} \mathrm{t}=+12^{\circ} \mathrm{C}\right)$ & 6.8 & 5.2 & 7.1 & $6.4 \pm 1.0$ \\
\hline & \multirow{3}{*}{ DKC 2787} & Early $\left(\mathrm{STR}^{*} \mathrm{t}=+8^{\circ} \mathrm{C}\right)$ & 9.9 & 8.3 & 8.9 & $9.0 \pm 0.8$ \\
\hline & & $\operatorname{Mid}\left(\mathrm{STR}=+10^{\circ} \mathrm{C}\right)$ & 8.9 & 7.5 & 8.6 & $8.3 \pm 0.7$ \\
\hline & & Late $\left(\right.$ STR $\left.\mathrm{t}=+12^{\circ} \mathrm{C}\right)$ & 8.2 & 6.1 & 8.0 & $7.4 \pm 1.2$ \\
\hline & \multirow{3}{*}{ DKC 2971 (st) } & $\operatorname{Early}\left(\mathrm{STR}^{*} \mathrm{t}=+8^{\circ} \mathrm{C}\right)$ & 10.0 & 7.8 & 9.0 & $8.9 \pm 1.1$ \\
\hline & & $\operatorname{Mid}\left(\mathrm{STR}=+10^{\circ} \mathrm{C}\right)$ & 9.8 & 7.7 & 8.8 & $8.8 \pm 1.1$ \\
\hline & & Late $\left(\mathrm{STR} \mathrm{t}=+12^{\circ} \mathrm{C}\right)$ & 8.9 & 6.3 & 7.8 & $7.7 \pm 1.3$ \\
\hline \multirow{21}{*}{ 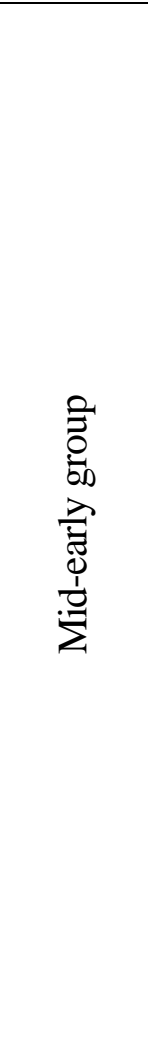 } & \multirow{3}{*}{ DKC 3476} & Early $\left(\mathrm{STR}^{*} \mathrm{t}=+8^{\circ} \mathrm{C}\right)$ & 10.4 & 8.7 & 10.0 & $9.7 \pm 0.9$ \\
\hline & & $\operatorname{Mid}\left(\mathrm{STR}=+10^{\circ} \mathrm{C}\right)$ & 10.5 & 7.6 & 9.5 & $9.2 \pm 1.5$ \\
\hline & & Late $\left(\mathrm{STR} \mathrm{t}=+12^{\circ} \mathrm{C}\right.$ ) & 8.3 & 6.2 & 8.8 & $7.8 \pm 1.4$ \\
\hline & \multirow{3}{*}{ DKC 3795} & Early $\left(\mathrm{STR}^{*} \mathrm{t}=+8^{\circ} \mathrm{C}\right)$ & 11.6 & 8.7 & 10.7 & $10.3 \pm 1.5$ \\
\hline & & $\operatorname{Mid}\left(\mathrm{STR}=+10^{\circ} \mathrm{C}\right)$ & 9.4 & 7.8 & 9.4 & $8.9 \pm 0.9$ \\
\hline & & Late $\left(\right.$ STR $\left.\mathrm{t}=+12^{\circ} \mathrm{C}\right)$ & 8.4 & 5.5 & 7.8 & $7.2 \pm 1.5$ \\
\hline & \multirow{3}{*}{ DKC 3472} & Early $\left(\mathrm{STR}^{*} \mathrm{t}=+8^{\circ} \mathrm{C}\right)$ & 11.8 & 9.5 & 11.5 & $10.9 \pm 1.3$ \\
\hline & & $\operatorname{Mid}\left(\mathrm{STR}=+10^{\circ} \mathrm{C}\right)$ & 10.8 & 9.2 & 10.1 & $10.0 \pm 0.8$ \\
\hline & & Late $\left(\right.$ STR $\left.\mathrm{t}=+12^{\circ} \mathrm{C}\right)$ & 9.4 & 7.4 & 9.1 & $8.6 \pm 1.1$ \\
\hline & \multirow{3}{*}{ DKC 3420} & Early $\left(\mathrm{STR}^{*} \mathrm{t}=+8^{\circ} \mathrm{C}\right)$ & 11.6 & 8.7 & 10.6 & $10.3 \pm 1.5$ \\
\hline & & $\operatorname{Mid}\left(\mathrm{STR}=+10^{\circ} \mathrm{C}\right)$ & 9.4 & 7.8 & 8.8 & $8.7 \pm 0.8$ \\
\hline & & Late $\left(\right.$ STR $\mathrm{t}=+12^{\circ} \mathrm{C}$ ) & 8.4 & 6.2 & 8.6 & $7.7 \pm 1.3$ \\
\hline & \multirow{3}{*}{ Pereiaslavskyi 230SV } & Early $\left(\mathrm{STR}^{*} \mathrm{t}=+8^{\circ} \mathrm{C}\right)$ & 11.2 & 8.8 & 9.3 & $9.8 \pm 1.3$ \\
\hline & & $\operatorname{Mid}\left(\mathrm{STR}=+10^{\circ} \mathrm{C}\right)$ & 9.1 & 8.6 & 8.6 & $8.8 \pm 0.3$ \\
\hline & & Late $\left(\mathrm{STR} \mathrm{t}=+12^{\circ} \mathrm{C}\right)$ & 8.3 & 5.8 & 8.4 & $7.5 \pm 1.5$ \\
\hline & \multirow{3}{*}{ DKC 3871 (st) } & Early $\left(\mathrm{STR}^{*} \mathrm{t}=+8^{\circ} \mathrm{C}\right)$ & 10.6 & 8.7 & 10.2 & $9.8 \pm 1.0$ \\
\hline & & $\operatorname{Mid}\left(\mathrm{STR}=+10^{\circ} \mathrm{C}\right)$ & 9.5 & 7.8 & 9.3 & $8.9 \pm 0.9$ \\
\hline & & Late $\left(\mathrm{STR} \mathrm{t}=+12^{\circ} \mathrm{C}\right)$ & 8.1 & 6.7 & 9.0 & $7.9 \pm 1.2$ \\
\hline & \multirow{3}{*}{ DK 391} & Early $\left(\mathrm{STR}^{*} \mathrm{t}=+8^{\circ} \mathrm{C}\right)$ & 12.6 & 10.6 & 10.8 & $11.3 \pm 1.1$ \\
\hline & & $\operatorname{Mid}\left(\mathrm{STR}=+10^{\circ} \mathrm{C}\right)$ & 10.6 & 8.7 & 9.7 & $9.7 \pm 1.0$ \\
\hline & & Late $\left(\mathrm{STR} t=+12^{\circ} \mathrm{C}\right)$ & 10.0 & 7.9 & 9.3 & $9.1 \pm 1.1$ \\
\hline
\end{tabular}

Source: formed on the basis of own research results 
Continuation of table 3

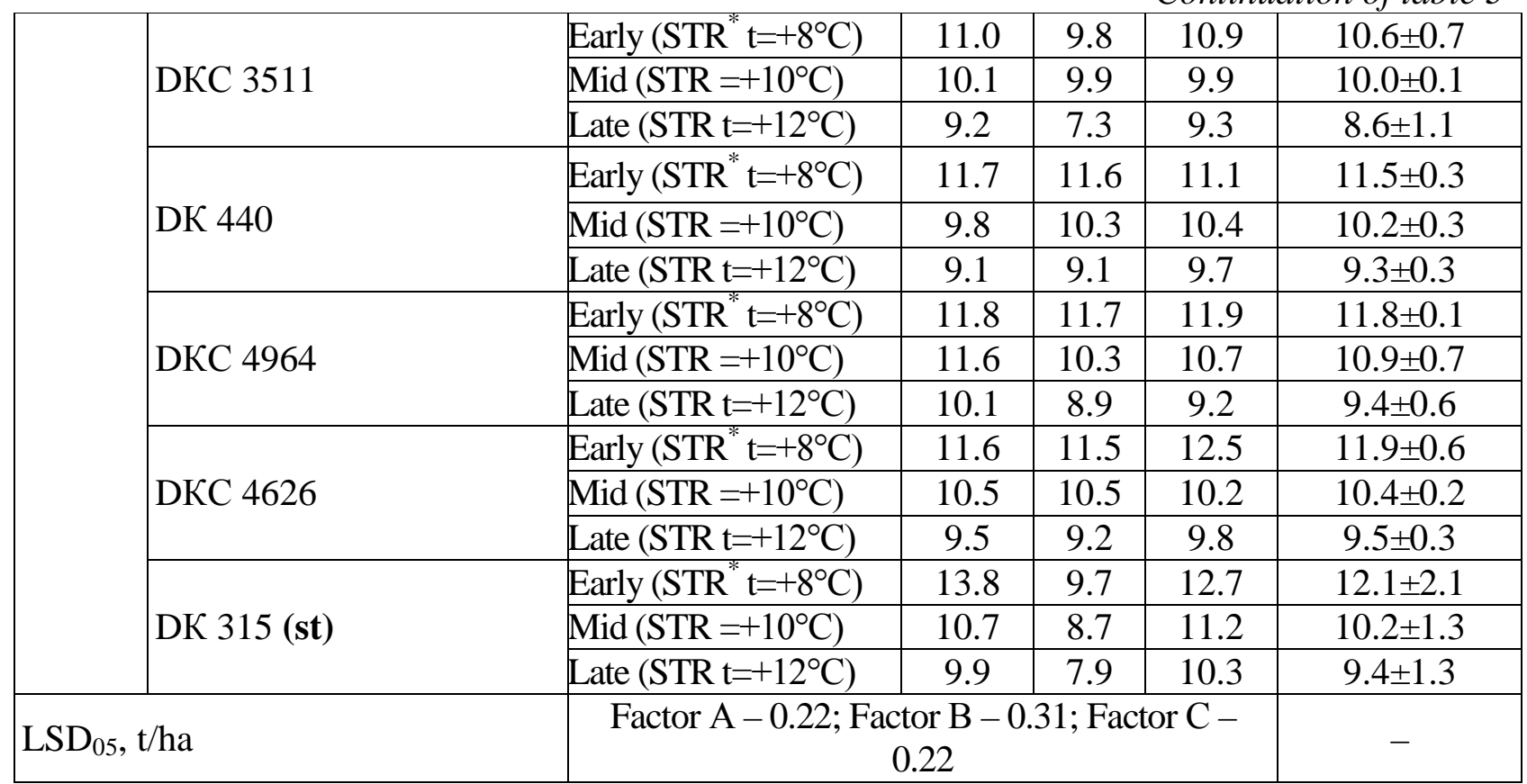

Note: STR- soil temperature regime at the seeding depth

Source: formed on the basis of own research results

DKC 3420 - 8.9 t/ha, mid group - DKC 4964 - 10.7 t/ha, DKC 4626 - 10.6 t/ha and DK 315 - $10.5 \mathrm{t} / \mathrm{ha}$, while the number of the lodged stalks in them was the following: early group - DKC $2971-7.4 \%$, DKC $2960-4.9 \%$ and DKC $2787-$ 19.0\%, mid-early group: DKC 3472 -10.1 \%, DKC $3871-12,3 \%$, DKC 3476 10,1\%, and DKC 3420 - 9,2\%, mid group: DKC $4964-3,6 \%$, DKC $4626-4,9 \%$ and DK $315-6.7 \%$.

As for the planting date, it also significantly (LSD 05 planting factor $\mathrm{C}=0.22 \mathrm{t} / \mathrm{ha}$ ) affected the productivity of corn hybrids and their lodging. In particular, under early planting date, the yield of the studied corn hybrids was $8.9 \mathrm{t} / \mathrm{ha}$ in early hybrids, 10.1 t/ha in mid-early, and $11.5 \mathrm{t} / \mathrm{ha}$ in mid hybrids, while it was $8.2 \mathrm{t} / \mathrm{ha}, 9.1$ and $10.2 \mathrm{t} /$ ha, respectively, under mid planting date, and $7.0 \mathrm{t} / \mathrm{ha}, 7.8 \mathrm{t} / \mathrm{ha}$ and $9.2 \mathrm{t} / \mathrm{ha}$, respectively, in the early, mid-early, and mid groups.

On average over three years of research, the yield ranged within 8.4-9.4 t / ha in the group of early hybrids sown under early planting date, under mid $-7.2-8.7 \mathrm{t} / \mathrm{ha}$, and under late - 6.4-7.7 t/ha, and the number of the lodged stalks was $17.1 \%, 10.5 \%$ and $5.6 \%$, respectively, under early planting date, mid and late. Mid-early hybrids sown under early planting date yielded in the range of 9.7-10.9 t/ha, mid one - 8.7$10.0 \mathrm{t} / \mathrm{ha}$, and late one $-7.2-8.6 \mathrm{t} / \mathrm{ha}$, the number of the lodged stalks amounted to $14.3 \%, 7.3 \%$ and $5.4 \%$ respectively.

The highest productivity was observed in the group of mid hybrids (11.5, 10.2 and $9.2 \mathrm{t} / \mathrm{ha}$ for the first, second and third planting periods) compared to the early and mid-early groups, while the number of the lodged stalks in them was the smallest, i.e. 10.4, 6.1 and 2.2\%, respectively, for the first, second and third planting periods. 
Conclusions. Therefore, according to the research results it can be concluded that later planting date reduces both the total number of the lodged stalks (by 8.2$11.5 \%)$ compared with the early sowing and the number of plants that have lodged below the place of cob formation (by 6.6-9.9\%). The smallest number of the lodged stalks $(6.2 \%)$ was observed in the hybrids of the mid group of maturity compared to the mid-early group $(9.0 \%)$ and early group $(11.1 \%)$ of hybrids. The same was observed with the number of the plants that have lodged below the cob - 3.3\%, 5.8\% and $6.0 \%$. There has been established the dependence between the yield and number of the lodged stalks depending on the planting time, so that the yield ranged within 8,4-9,4 t/ha in the group of early hybrids under early planting , 7.2-8.7 t/ha under mid one, 6.4-7.7 t/ha under late one, and the number of fall lodged stalks $-17.1 \%, 10.5 \%$ and $5.6 \%$ respectively under early planting, mid planting and late planting, in the mid-early group - 9.7-10.9 t/ha, under mid planting $-8.7-10.0 \mathrm{t} / \mathrm{ha}$, late $-7.2-8.6$ $\mathrm{t} / \mathrm{ha}$, and the number of the lodged stalks $-14.3 \%, 7.3 \%$ and $5.4 \%$ and mid hybrids 11.5, 10.2 and $9.2 \mathrm{t} /$ ha and $10.4,6.1$ and $2.2 \%$, respectively.

According to the factor analysis, it has been established that the planting date makes a significant contribution (17\% of the total contribution) to the lodging resistance of plants of corn hybrids.

The number of the lodged stalks varies considerably depending on the conditions of heat and moisture supply. An increase in the number of the lodged stalks was observed in 2012 (11.6\%), compared to 2011 (10.8\%) and 2013 (3.9\%) due to the moisture deficiency during the growing season of corn that year.

\section{Список використаної літератури}

1. Прокопенко О. М. Рослинництво України (Crop production of Ukraine). Статистичний збірник (Statistical yearbook). К. 2016. С. 94-96.

2. Андрієнко O., Андрієнко А., Кузьмич В. Види та причини вилягання кукурудзи - як їм запобігти. Пропозииія. 2017. № 4. С. 82-90.

3. Vitalii Palamarchuk, Natalia Telekalo. The effect of seed size and seeding depth on the components of maize yield structure. Bulgarian Journal of Agricultural Science, 24 (№ 5) 2018, 783-790.

4. Мазур В. А., Паламарчук В. Д., Поліщук І. С., Паламарчук О. Д. Новітні агротехнології у рослинництві: Підручник. Вінниця, 2017. 588 с.

5. Евтушенко Ю. В., Гридньова Н. М., Курасов В. С. Косвенный метод оценки кукурузы на устойчивость к полеганию. Кукуруза и сорго. 1999. № 1. C. 2-4.

6. Зеленский М. А., Гора И. Б. Воздушные корни как фактор устойчивости растений к полеганию. Вісник аграрної науки. 1991. № 10. С. 29-30.

7. Паламарчук В.Д. Залежність стійкості до вилягання рослин самозапилених ліній кукурудзи від морфологічних ознак. Корми $i$ кормовиробництвво. 2006. Вип. 57. С. 67-71. 
8. Паламарчук В. Д., Мазур В. А., Зозуля О. Л. Кукурудза селекція та вирощування гібридів: [Монографія]. Вінниця, 2009. 199 с.

9. Зозуля О. Л., Паламарчук В. Д. Оцінка вихідного матеріалу кукурудзи при селекції на стійкість до вилягання. Збірник матеріалів студентської науковопрактичної конференції. Вінниця, 2006. С. 46.

10. Паламарчук В.Д., Мазур В. А. Вплив тривалості фенологічних фаз на стійкість кукурудзи до вилягання. Вісник Львівського державного аграрного університету. Серія „Агрономія”. 2009. №13. С. 358-362.

11. Лебідь Є. М., Циков В. С., Пащенко Ю. М. [та ін.]. Методика проведення польових дослідів з кукурудзою. Дніпропетровськ, 2008. 27 с.

12.Вовкодав В. В. Методика державного сортовипробування сільськогосподарських культур (зернові, круп’яні та зернобобові). К.: 2001. $64 \mathrm{c}$.

13. Мельник С. Методика проведення експертизи сортів рослин групи зернових, круп'яних та зернобобових на придатність до поширення в Україні. (Міністерство аграрної політики та продовольства України. Український інститут експертизи сортів рослин). 2016. 81 с.

14. Statistica 6 [Електронний ресурс]: Пакет програм для статистичного аналізу даних. 1 електрон, опт. диск (CD-ROM).

15. Дроздов В. И. Инструкция по использованию пакета Statistica 6.0. Курск: Юго-Западный государственный университет, 2013. 74 с.

\section{Список викоитсаної літератури у транслітерації /References}

1. Prokopenko O. M. (2016). Roslynnytstvo Ukrainy [Crop production of Ukraine]. Statystychnyi zbirnyk - Statistical yearbok. Kyiv. [in Ukrainian].

2. Andriienko O., Andriienko A., Kuzmych V. (2017). Vydy ta prychyny vyliahannia kukurudzy - yak yim zapobihty [Types and causes of corn lodging - how to prevent them]. Propozytsiia - Proposition, 4, 82-90. [in Ukrainian].

3. Palamarchuk V., Telekalo N. (2018). The effect of seed size and seeding depth on the components of maize yield structure. Bulgarian Journal of Agricultural Science, 24. 5. 783-790. [in English].

4. Mazur V.A., Palamarchuk V.D., Polishchuk I.S., Palamarchuk O.D. (2017). Novitni ahrotekhnolohii u roslynnytstvi: Pidruchnyk. [Advanced agrotechnologies in crop production: Textbook]. Vinnytsia. [in Ukrainian].

5. Evtushenko Y. V., Gridnova N. M., Kurasov V. S. (1999). Kosvennyy metod otsenki kukuruzy na ustoychivost k poleganiyu [Indirect method of evaluation of corn lodging resistance] . Kukuruza i sorgo - Corn and Sorghum, 1, 2-4. [in Russian].

6. Zelenskiy M.A., Gora I.B. (1991). Vozdushnyye korni kak faktor ustoychivosti rasteniy k poleganiyu [Air roots as a factor of plant lodging resistance]. Visnik agrarnoï nauki - Bulletin of Agrarian Science, 10, 29-30. [in Ukrainian]

7. Palamarchuk V.D. (2006). Zalezhnist stiikosti do vyliahannia roslyn samozapylenykh linii kukurudzy vid morfolohichnykh oznak [Dependence of the lodging resistance of self-pollinated corn lines on the morphological characteristics]. Kormy $i$ 
kormovyrobnytstvo. - Feeds and feed production. Issue 57.67-71. [in Ukrainian].

8. Palamarchuk V. D., Mazur V. A., Zozulia O. L. (2009). Kukurudza selektsiia ta vyroshchuvannia hibrydiv [Corn Selection and Growing of Hybrids]. Vinnytsia [in Ukrainian].

9. Zozulia O. L., Palamarchuk V. D. (2006). Otsinka vykhidnoho materialu kukurudzy pry selektsii na stiikist do vyliahannia [Estimation of the primary material of corn when breeding for lodging resistance]. Zbirnyk materialiv studentskoi naukovopraktychnoi konferentsii. - Collection of materials of the student's scientific-practical conference. Vinnytsia [in Ukrainian].

10. Palamarchuk V. D., Mazur V. A. (2009). Vplyv tryvalosti fenolohichnykh faz na stiikist kukurudzy do vyliahannia [The effect of the duration of phenological phases on corn lodging resistance]. Visnyk Lvivskoho derzhavnoho ahrarnoho universytetu. Seriia „Ahronomiia”. - Visnyk of Lviv State Agrarian University. Agronomy series. 13, 358362 [in Ukrainian].

11. Lebid Y.M., Tsykov V.S., Pashchenko Yu.M. et.al. (2008). Metodyka provedennia polovykh doslidiv $\mathrm{z}$ kukurudzoiu. Dnipropetrovsk [Methodology of conducting field experiments with corn]. Dnipropetrovask [in Ukrainian].

12. Vovkodav V.V. (2001). Metodyka derzhavnoho sortovyprobuvannia silskohospodarskykh kultur (zernovi, krupiani ta zernobobovi). [The method of state variety testing of agricultural crops (grain, cereals and leguminous plants)]. Kyiv [in Ukrainian].

13. Melnyk S. (2016). Metodyka provedennia ekspertyzy sortiv roslyn hrupy zernovykh, krupianykh ta zernobobovykh na prydatnist do poshyrennia $\mathrm{v}$ Ukraini. (Ministerstvo ahrarnoi polityky ta prodovolstva Ukrainy. Ukrainskyi instytut ekspertyzy sortiv roslyn). [The method of expert examination of plant varieties of grains, cereals and legumes for suitability for distribution in Ukraine. (Ministry of Agrarian Policy and Food of Ukraine, Ukrainian Institute of Plant Varieties Examination)]. [in Ukrainian].

14. Statistica 6 [Elektronnyi resurs]: Paket prohram dlia statystychnoho analizu danykh. 1 elektron, opt. dysk (CD-ROM). [Software package for statistical analysis of data. 1 electron, opt. CD (CD-ROM)]. [in Russian]

15. Drozdov V. I. (2013). Instruktsiya po ispolzovaniyu paketa Statistica 6.0. [Instructions for using Statistica 6.0.]. Kursk: Yugo-Zapadnyy gosudarstvennyy universitet. [in Russian].

\section{АНОТАЦИ \\ ВПЛИВ СТРОКІВ СІВБИ НА СТІЙКІСТЬ ГІБРИДІВ КУКУРУДЗИ ДО ВИЛЯГАННЯ}

Встановлення впливу термінів сівби на кількість полеглих рослин, місие зламу стебла та продуктивність гібридів кукурудзи різних груп стиглості. Польовий, лабораторний, статистичний. В процесі досліджень вивчалися три строки сівби ранній за рівня температурного режиму трунту (РТГ) на глибині загортання насіння $+8^{\circ} \mathrm{C}$, середній за РТГ- $+10^{\circ} \mathrm{C}$ та пізній за РТГ $-+12^{\circ} \mathrm{C}$, гібридів кукурудзи 
різних груп стиглості (ранньостиглої групи - Харківський 195МВ, DКС 2870, DKC 2960, DKC 2949, DKC 2787, DKC 2971 (st), середньоранньої- DKC 3476, DKC 3795, DKC 3472, DKC 3420, Переяславський 230CB, DKC 3871 (st) ma середньостиглої-DK 391, DKC 3511, DK 440, DKC 4964, DKC 4626, DK 315 (st)) та їх вплив на рівень продуктивності та кількість полеглих рослин за 15ти денного перестою рослин в полі після настання повної стиглості зерна. Результатами проведених досліджень встановлено, щзо кількість полеглих рослин в групі ранньостиглих гібридів склала 11,1\%, в групі середньоранніх гібридів - 9,0\% та в групі середньостиглих гібридів - 6,2\%. Тобто, спостерігається тенденція при якій гібриди із тривалішим вегетаційним періодом, за рахунок краще розвиненої механічної тканини нижньої частини стебла, мають вищу стійкість до вилягання порівняно із ранньостиглими формами. В групах стиглості відмічено суттєву зміну кількості полеглих рослин залежно від генетичних особливостей гібриду. Так, у групі ранньостиглих гібридів найменшу кількість полеглих рослин, за роки досліджень, відмічено у гібридів DКС 2960 - 4,9\% та DКС 2971 - 7,4\%, у групі середньоранніх гібридів - DКС 3476 - 4,6\% та Переяславський 230СВ 8,2\%, а у групі середньостиглих гібридів DKC 4964 - 3,6\%, DKC 4626 - 4,9\%, DK 391 - 5,1\% та DK 440 - 5,8\%. Результатами проведених досліджень також встановлений вплив строків сівби на продуктивність та кількість полеглих рослин у досліджуваних гібридів кукурудзи. Так при застосуванні раннього строку сівби кількість полеглих рослин, в середньому за три роки, в групі ранньостиглих гібридів склала - 17,1\%, в групі середньоранніх гібридів - 14,3\% та в групі середньостиглих гібридів - 10,4\%, тоді як при застосуванні другого строку сівби кількість полеглих рослин становила - 10,5\%, 7,3 та 6,1\%, а при застосуванні пізнього строку сівби 5,6\%, 5,4 ma 2,2\%, відповідно для ранньостиглої, середньоранньої та середньостиглої групи гібридів. На основі отриманих результатів можна стверджувати, що запізнення із строками сівби зменшує, як загальну кількість полеглих рослин (на 8,2-11,5\%) порівняно із раннім посівом, так і кількість рослин, які вилягли нижче місия закладання качанів (на 6,6-9,9\%). Найменшу кількість полеглих рослин (6,2\%) мали гібриди середньостиглої групи, порівняно із середньоранньою $(9,0 \%)$ та ранньостиглою $(11,1 \%)$ групою гібридів, така ж тендениія стосується кількості полеглих рослин нижче качана - 3,3\%, 5,8 та 6,0\%. Встановлена залежність між урожайністю та кількістю полеглих рослин залежно від строків сівби, так у групі ранньостиглих гібридів за раннього строку посіву рівень урожайності коливався в межах 8,4-9,4 m/2а, за середнього - 7,28,7 m/2a, за пізнього - 6,4-7,7 m/2a, а кількість полеглих рослин - 17,1\%, 10,5\% та 5,6\% відповідно за раннього строку сівби, середнього та пізнього, у групі середньоранніх гібридів - 9,7-10,9 m/2а, середнього - 8,7-10,0 m/2а, пізнього - 7,28,6 m/2а, а кількість полеглих рослин - 14,3\%, 7,3\% та 5,4\% і середньостиглих гібридів-11,5; 10,2 та 9,2 m/2а і 10,4; 6,1 ma 2,2\%, відповідно. Встановлено, що строки сівби здійснюють значний вклад (17\% загального вкладу) на стійкість рослин гібридів кукурудзи до вилягання. 
Ключові слова: зерно, кукурудза, гібрид, кількість полеглих рослин, група стиглості, строки сівби, урожайність.

Табл. 3. Рис. 1. Літ. 15.

\section{АННОТАЦИЯ}

\section{ВЛИЯНИЕ СРОКОВ ПОСЕВА НА УСТОЙЧИВОСТЬ ГИБРИДОВ КУКУРУЗЫ К ПОЛЕГАНИЮ}

Изучение влияния сроков сева на устойчивость растений к полеганию, места излома стебля и продуктивности гибридов кукурузы различных групп спелости. $B$ исследованиях изучались три срока посева: ранний при уровне температурного режима почвы (УТП) на глубине заделки семян $+8^{\circ} \mathrm{C}$, средний при УТП $-+10^{\circ} \mathrm{C}$ и поздний при УТП - $+12^{\circ} \mathrm{C}$, гибридов кукурузы различных групп спелости (раннеспелой группь - Харьковский 195 MB, DKC 2870, DKC 2960, DKC 2949, DKC 2787, DKC 2971 (st), среднеранней-DKC 3476, DKC 3795, DKC 3472, DKC 3420, Переяславский 230CB, DKC 3871 (st) и среднеспелой - DK 391, DKC 3511, DK 440, DKC 4964, DKC 4626, DK 315 (st) и их влияние на количество павших растений при 15-дневном перестое в поле после наступления полной спелости зерна. Результатами проведенных исследований установлено, что количество павших растений в группе раннеспельх гибридов составило 11,1\%, в группе среднеранних гибридов - 9,0\% и в группе среднеспелых гибридов - 6,2\%. То есть, наблюдается тенденция при которой, гибриды с длительными вегетационным периодом, за счет лучше развитой механической ткани нижней части стебля, имеют высокую устойчивость к полеганию по сравнению с раннеспельми формами. В группах спелости отмечено существенное изменение количества павших растений в зависимости от генетических особенностей гибрида. Так, в группе раннеспельх гибридов наименьшее количество павших растений, за годы исследований, отмечено у гибридов DKC 2960 - 4,9\% и DKC 2971 - 7,4\%, в группе среднеранних гибридов DKC 3476 - 4,6\% и Переяславский $230 C B-8,2 \%$, а в группе среднеспельх гибридов DKC 4964 - 3,6\%, DKC 4626 - 4,9\%, DK 391 - 5,1\% и DK 440 - 5,8\%. Результатами проведенных исследований также установлено влияние сроков сева на продуктивность и количество павших растений в исследуемых гибридов кукурузы. При применении раннего срока сева количество полегльхх растений, в среднем за три года, в группе раннеспельх гибридов составило - 17,1\%, в группе среднеранних гибридов - 14,3\% и в группе среднеспельх гибридов-10,4\%, тогда как при применении второго срока сева количество полеглых растений составило 10,5\%, 7,3 и 6,1\%, а при применении позднего срока сева - 5,6\%, 5,4 и 2,2\%, соответственно для раннеспелой, среднеранней и среднеспелой группь гибридов. На основании полученных результатов можно утверждать, что опоздание со сроками сева уменьшает, как общее количество полегльх растений (на 8,2-11,5\%) по сравнению с ранним посевом, так и количество растений, которые полегли ниже места закладки початков (на 6, 6-9,9\%). Наименьшее количество павших растений (6,2\%) имели гибриды среднеспелой группы, по сравнению с среднеранней $(9,0 \%)$ и раннеспелой $(11,1 \%)$ группой гибридов, такая же тенденция касается 
количества полегльх растений ниже початка - 3,3\%, 5,8 и 6,0\%. Установлена зависимость между урожайностью и количеством полегльх растений $в$ зависимости от сроков сева, так в группе раннеспельх гибридов при раннем сроке посева уровень урожайности колебался в пределах 8,4-9,4 m/2а, при среднем - 7,28,7 m/2а, и при позднем - 6,4-7,7 m/2а, а количество полегльх растений - 17,1\%, 10,5\% и 5,6\%, в группе среднеранних гибридов - 9,7-10,9 m/2а, среднем - 8,7-10,0 $\mathrm{m} / 2 a$, позднем - 7,2-8,6 m/2a, а количество полегльх растений - 14,3\%, 7,3\% и 5,4\% и среднеспельх гибридов - 11,5; 10,2 и 9,2 m/2a u 10,4; 6,1 и 2,2\%, соответственно в ранний срок сева, средний и поздний. Согласно проведенного факторного анализа установлено, что сроки сева осущзествляют значительный вклад - 17\% в устойчивость растений гибридов кукурузы к полеганию. Количество полеалых растений существенно меняется в зависимости от условий тепло- $u$ влагообеспеченности. Увеличение количества полегльх растений наблюдали в 2012 году (11,6\%) по сравнению с 2011 (10,8\%) и 2013 (3,9\%) годом, за счет дефицита влаги в период вегетации кукурузы в этом году.

Ключевые слова: зерно, кукуруза, гибрид, количество погибиих растений, группа спелости, сроки сева, урожайность.

Табл. 3. Рис. 1. Лит. 15.

\section{Author's profile}

Паламарчук Віталій Дмитрович - кандидат сільськогосподарських наук, доцент кафедри рослинництва, селекції та біоенергетичних культур Вінницького національного аграрного університету (21008, м. Вінниця, вул. Сонячна, 3, e-mail: vd-palamarchuk@ukr.net).

Колісник Олег Миколайович - кандидат сільськогосподарських наук, доцент кафедри ботаніки, генетики та захисту рослин Вінницького національного аграрного університету(21008, м. Вінниця, вул. Сонячна, 3, еmail: ooo@i.ua).

Паламарчук Виталий Дмитриевич - кандидат с.-х. наук, доцент кафедры растениеводства, селекции и биоэнергетических культур Винницкого национального аграрного университета (21008, г. Винница, ул. Солнечная, 3 еmail: vd-palamarchuk@ukr.net).

Колесник Олег Николаевич - кандидат с.-х. наук, доцент кафедры ботаники, генетики и защиты растений Винницкого национального аграрного университета (21008, г. Винница, ул. Солнечная, 3 e-mail: ooo@i.ua).

Palamarchuk Vitalii - Candidate of Agricultural Sciences, Associate Professor of the Department of Plant Production, Selection and Bioenergetic cultures (21008, Vinnytsia, Soniachna Str. 3, e-mail: vd-palamarchuk@ukr.net).

Kolisnyk Oleh - Candidate of Agricultural Sciences, Associate Professor of the Department of Botany, Genetics and Plant Protection, Vinnytsia National Agrarian University (21008, Vinnytsia, Soniachna Str. 3). 